\title{
High Tunnel and Organic Horticulture: Compost, Food Safety, and Crop Quality
}

\author{
Patricia Millner \\ USDA-ARS, Sustainable Agricultural Systems Laboratory, 10300 Baltimore Avenue, Building 001, Room 140, \\ Beltsville, MD 20866; and Environmental Microbiology and Food Safety Laboratory, Beltsville, MD 20705 \\ Sara Reynolds \\ USDA-ARS, Sustainable Agricultural Systems Laboratory, 10300 Baltimore Avenue, Building 001, Room 140, \\ Beltsville, MD 20866 \\ Xiangwu Nou \\ Environmental Microbiology and Food Safety Laboratory, Beltsville, MD 20705 \\ Donald Krizek \\ USDA-ARS, Sustainable Agricultural Systems Laboratory, 10300 Baltimore Avenue, Building 001, Room 140, \\ Beltsville, MD 20866
}

Additional index words. season extension, phytonutrient composition, phenolics, food safety, good agricultural practices, fresh fruits and vegetables, local produce, UV exclusion, manure, compost tea

\begin{abstract}
High tunnels and protected horticultural structures provide organic and conventional growers with an economic means for extending the harvest season of fresh fruits and vegetables in a wide range of climate zones in North America and elsewhere. This report focuses on benefits associated with high tunnel production of fresh organic produce, including recent data on phytonutrient quality. In addition, this report discusses concerns and knowledge gaps associated with the use of composts and manures relative to food safety of fresh produce and survival of enteric pathogens in the moist, cool, reduced ultraviolet conditions often prevalent in high tunnels during cool-season production. The role of preplant and production elements of Good Agricultural Practices and Good Handling Practices applicable to high tunnel systems is provided.
\end{abstract}

The increasing use of plastic film-covered structures such as high and low tunnels in many areas of the United States have enabled growers to extend the cropping season with earlier spring planting and later fall harvesting without extensive environmental controls common in traditional greenhouses (Jett and Quinn, 2005; Lamont et al., 2003). In addition, selective choice of plastic film type for these protected structures has been shown to aid control of Botrytis and insects as well as plant growth (Krizek et al., 2005a). Other benefits of high tunnel production include soil warming during periods of low ambient temperatures and reduced moisture fluctuations within the sheltered environment, weediness from reduced deposition of external sources of windblown seed, crop damage from wind and rain events, incidence of physiological ripening disorders from sun scorch, and chemical use from more effective use of biocontrols (Jett and Quinn, 2005; Lamont et al., 2003). Protected structures also appeal to direct market producers because of low capital investment and operating costs and the extended season advantage of fresh produce sales in local markets. They are used by organic as well as conventional growers in a wide range of climates in which efficient use of fertilizers in vegetable and small fruit cropping systems is needed (Romanowski, 1981).

Despite these benefits, it is unclear what effects the different film types have on various cultivars and plants relative to early

Received for publication 11 Nov. 2008. Accepted for publication 27 Jan. 2009. harvest and improved produce quality attributes. Furthermore, some conditions such as low winter temperatures coupled with increased humidity, high organic matter soils, and low ultraviolet exposure from various film types may be more conducive to survival of inadvertently introduced foodborne illness pathogens, phytopathogens, or pests.

\section{COMPOST}

Although production in protected structures occurs with soilless media such as coir, peat, perlite, pine bark, rockwool, or vermiculite and inorganic nutrient solutions (Cantliffe et al., 2003; Peet et al., 2004), such methods do not reflect basic organic system principles. Most organic production systems are based on improving and maintaining high soil quality. Composted organic matter is commonly used in organic, and some conventional high tunnel or protected structure systems, in mid- to northernlatitude growing regions in the United States to improve and maintain soil quality. Compost has long been used as a beneficial soil amendment in horticulture because it suppresses certain plant diseases, improves moisture retention and cation exchange capacity, provides micronutrients, slowrelease nitrogen, and organic matter (Stoffella and Kahn, 2001). Growers interested in resource conservation also appreciate that locally produced compost substitutes for peat and other nonrenewable products and provides supportive enterprises for recycling horticultural industry organic residuals while avoiding landfill expenses and provides retail product market options. Also, many conventional producers also rely on compost to maintain soil organic matter, particularly in intensive systems that do not have a substantive cover crop period by which to reduce populations of crop pests and phytopathogens that target their primary crops.

Organic food as defined in the U.S. Organic Foods Production Act (USDA, 2000 ) is a marketing term for items produced under the authority of the National Organic Program. The organic production approach is based on minimizing off-farm inputs and synchronizing management practices with natural biological cycles and processes to maintain and improve agroecosystem productivity while reducing adverse environmental impacts. Fresh fruits and vegetables have led all categories of organic food and feed sales in the United States since 1996 when recordkeeping on organic production began and are leading the expanding global demand for organic products (NBS, 2006). California continues to have the largest number of acres in organic fields $(60 \%)$ and protected structures $(20 \%)$ compared with other states (Green, 2008). However, many small farm (less than 5 to 50 acre) operators are responding to the increased market demand for fresh local organic produce. Organic and/or local produce appeals to consumers interested in produce that has minimal risk of containing pesticide and agrichemical residues and is at its peak quality, flavor, and freshness. Also, some consumers are interested in supporting local agriculture to preserve open spaces within regional communities. The reduced impacts from avoiding fossil fuel and combustion 
emissions that accrue from minimizing long, complex food distribution chains recently have added to the appeal of local fresh produce. Like with all produce types, consumer confidence in the safety, nutrition, and wholesomeness has a direct impact on purchase decisions. Perceived or actual knowledge of production inputs and a range of conditions such as pesticide and manure use, soil conservation, water quality, and postharvest processing as well as worker justice and community impacts can affect consumer confidence.

Organic producers may rely on use of manure and manure-based inputs to supply part of the crop nitrogen $(\mathrm{N})$ needs. Composts typically have low $\mathrm{N}$ content, ranging from $0.8 \%$ to $2.0 \%$, for mature compost that is stabilized and no longer phytotoxic (Stoffella and Kahn, 2001). Consequently, additional N must be supplied from other sources, which may include legume cover crops, blood and feather meal, and pelletized poultry litter with carefully timed applications. The recognized presence of pathogenic microbes of public health importance in raw animal manure (Table 1) (Bowman, 2009; Cooper et al., 2007) requires that use of raw or composted manure in USDA-certified organic production systems follow specific conditions and practices. If raw manure is used, then harvest may not occur before $90 \mathrm{~d}$ if the harvestable portion does not directly contact the soil to which the raw manure was added or $120 \mathrm{~d}$ if the harvestable portion directly contacts the amended soil (USDA, 2000). Composted manure is defined in the National Organic Program as the product of a managed process through which microorganisms decompose plant or animal matter mixtures with initial $\mathrm{C}: \mathrm{N}$ ratios of $25: 1$ to 40:1 into more plant-available forms suitable for soil application. In-vessel or static aerated pile composts are required to maintain a

Table 1. Some pathogenic microorganisms of public health concern in manure.

\begin{tabular}{l}
\hline \multicolumn{1}{c}{ Bacteria } \\
\hline Campylobacter coli and C. jejuni \\
Bacillus anthracis \\
Brucella abortus \\
Escherichia coli patho- and toxigenic strains \\
Leptospira spp. \\
Listeria monocytogenes \\
Mycobacterium bovis \\
Mycobacterium avium paratuberculosis \\
Salmonella spp. \\
Yersinia enterocolitica \\
Viruses \\
Avian-Swine influenza \\
Hepatitis E Parasites \\
Protozoa \\
Balatidium coli \\
Cryptosporidium parvum \\
Giardia spp. \\
Toxoplasma spp. \\
Helminths \\
Ascaris suum \\
Taenia spp. \\
Trichuris trichiura \\
\hline
\end{tabular}

temperature of 55 to $76^{\circ} \mathrm{C}$ (131 to $\left.170{ }^{\circ} \mathrm{F}\right)$ for $3 \mathrm{~d}$ continuously, whereas windrow composts must achieve these temperatures for 15 $\mathrm{d}$, during which time the materials must be turned a minimum of five times. These criteria are designed to destroy the most resistant zoonotic pathogens (helminth ova), the exception being spore-forming bacteria such as Bacillus spp. or Clostridium spp.; however, plant pathogens also are destroyed (Stoffella and Kahn, 2001). Simple stacking of manure without managing it or providing a recommended insulated cover layer on static aerated piles, recording temperatures, or turning at appropriate intervals will not ensure adequate destruction of pathogens like Escherichia coli $\mathrm{O} 157: \mathrm{H} 7$ in the unheated exterior zone. Test-certified compost with undetectable E. coli, Salmonella, or Listeria monocytogenes would provide users assurance of the product quality.

\section{COMPOST TEA}

Compost tea (CT) is of interest to organic and other producers as a biocontrol spray for foliar plant diseases or a soil drench for root diseases and plant health (Scheuerell and Mahaffee, 2004). A variety of equipment, brewing methods, and additives are available for production of CT. However, additives purported to increase the beneficial micro-organisms that impact the biocontrol effect have been shown to support growth of E. coli $\mathrm{O} 157: \mathrm{H} 7$ and Salmonella enterica sv. Typhimurium (Ingram and Millner, 2007).

For use in certified organic production, CT prepared from compost made with manure would at least need to meet the thermophilic, time-temperature, and management standards described here. Raw manure, partially composted manure, or commercial food waste would not be suitable for CT production within the certified organic program.

\section{FOOD SAFETY}

Foodborne illnesses associated with consumption of fresh fruits and vegetables in the United States over several years have increased concern by consumers as well as the producer-marketer and public health sectors about possible contamination from enteric pathogens at the primary field production stage. Between 1990 and 1998, 24\% of foodborne illness outbreaks associated with consumption of contaminated produce nearly equaled outbreaks associated with meat consumption (29\%) and several outbreaks involved small, organic gardens in which raw manure had been applied (Cieslak et al., 1993; Nelson, 1997). The types of fresh produce associated with illness outbreaks include many that are now being grown in high tunnels and other protected horticultural structures (Table 2).

The protection afforded by tunnels and other structural and season-extending horticultural innovations would appear to have inherent benefits against fugitive enteric pathogen contamination from some implicated sources such as certain wildlife. However, other suspected sources of enteric pathogens such as contaminated water and manure-based soil amendments, proximity to livestock and poultry operations, equipment, and overall poor sanitation remain as elements that must be managed through purposeful use of Good Agricultural Practices (GAPs) and Good Handling Practices (GHPs) (Table 3). Both GAPs and GHPs (www.gaps.cornell.edu) aim to reduce microbial contamination risks to fresh fruits and vegetables.

Table 2. Types of greens, herbs, fruits, and vegetables grown in high tunnels.

\begin{tabular}{|c|c|}
\hline \multicolumn{2}{|c|}{ Greens } \\
\hline Amaranth-Amaranthus tricolor L. & Dandelion-Taraxacum officinale L. \\
\hline Arugula-Eruca sativa $\mathrm{L}$. & Lettuce-Lactuca sativa L. multiple varieties \\
\hline Beet-Beta vulgaris L. & $\begin{array}{l}\text { Mizuna-Brassica rapa subsp. nipposinica } \\
\text { (L.H. Bailey) Hanelt }\end{array}$ \\
\hline Cabbage_-Brassica oleracea var. capitata L. & Mustards-Brassica juncea multiple varieties \\
\hline Chard-Beta vulgaris var. cicla $\mathrm{L}$. & Radicchio-Cichorium intybus L. \\
\hline Cress-Lepidium sativum $\mathrm{L}$. & Shungiku-Chrysanthemum coronarium $\mathrm{L}$. \\
\hline Chicory, endive, escarole-Cichorium & Spinach-Spinacea oleracea L. \\
\hline
\end{tabular}
endivia $\mathrm{L}$.

Herbs

\begin{tabular}{|c|c|}
\hline \multirow{2}{*}{\multicolumn{2}{|c|}{ Parsley-Petroselinum crispum (Mill.) }} \\
\hline & Parsley-Petroselinum crispum (Mill.) \\
\hline Chives-Allium schoenoprasum L. & Nyman ex A.W. Hill \\
\hline Cilantro-Coriandrum sativum $\mathrm{L}$. & Rosemary-Rosmarinus officinalis L. \\
\hline Dill—Anethum graveolens L. & Sage_-Salvia officinalis L. \\
\hline Lemon balm-Melissa officinialis L. & Shiso-Perilla frutescens (L.) Britton \\
\hline Marjoram-Origanum majoraca L. & Sorrel-Rumex acetosa $\mathrm{L}$. \\
\hline Mint-Mentha spp. & Tarragon-Artemisia dracunculus L. \\
\hline Nasturtium-Tropaeolum majus L. & Thyme-Thymus spp., multiple varieties \\
\hline \multicolumn{2}{|c|}{ Vegetables and berries } \\
\hline Broccoli-Brassica oleracea var. italica Plenck & Onion-Allium cepa L. \\
\hline Carrots-Daucus carota var. sativus Hoffm. & Radish-Raphanus sativus L. \\
\hline Cucumber-Cucumis sativus L. & Raspberry-Rubus idaeus L. \\
\hline Daikon-Raphanus sativus L. & Strawberry-Fragaria $\times$ ananassa Duch. \\
\hline longipinnatus Bailey & Squash_-Cucurbita pepo L. \\
\hline Melons-Cucumis melo L. & Tomato-Lycopersicon esculentum Mil \\
\hline
\end{tabular}


Table 3. Key elements of Good Agricultural Practices (GAPs) and Good Handling Practices (GHPs) for site preparation and crop production steps applicable to high tunnel and open field organic and conventional production systems.

\begin{tabular}{|c|c|}
\hline Step & Element \\
\hline \multirow[t]{6}{*}{ Preplant } & $\begin{array}{l}\text { 1. Select produce field sites carefully, avoid proximity to } \\
\text { livestock and poultry operations }\end{array}$ \\
\hline & 2. Store manure properly to avoid runoff and dust dispersal to crops \\
\hline & $\begin{array}{l}\text { 3. Treat manure properly to destroy pathogens and stabilize nutrients; } \\
\text { test treated manure for pathogens before use in fresh produce systems }\end{array}$ \\
\hline & $\begin{array}{l}\text { 4. Use clean equipment; clean manure handling equipment to avoid } \\
\text { crosscontamination with crop production equipment, including } \\
\text { trucks and loaders }\end{array}$ \\
\hline & 5. Time manure applications to ensure adequate time lapse to harvest date \\
\hline & $\begin{array}{l}\text { 6. Plant crops at appropriate times so that harvest will not occur } \\
\text { before adequate time has lapsed since last application of manure }\end{array}$ \\
\hline \multirow[t]{7}{*}{ Production } & $\begin{array}{l}\text { 1. Avoid use of raw or inadequately composted manure on direct contact } \\
\text { fresh produce crops; consider testing the manure before use to } \\
\text { assess presence of pathogens }\end{array}$ \\
\hline & $\begin{array}{l}\text { 2. Take measures to exclude domestic animals and wildlife } \\
\text { from crops/tunnels }\end{array}$ \\
\hline & $\begin{array}{l}\text { 3. Train workers in hygienic job practices and provide in-field } \\
\text { hand-wash and toilet facilities }\end{array}$ \\
\hline & $\begin{array}{l}\text { 4. Test and remediate (if necessary) irrigation water quality at } \\
\text { regular intervals; avoid surface water sources and open } \\
\text { impoundments used by wildlife, unless disinfecting treatment } \\
\text { is implemented before use on crops. }\end{array}$ \\
\hline & $\begin{array}{l}\text { 5. Use a water-efficient irrigation method that avoids direct } \\
\text { contact with produce if water is not potable }\end{array}$ \\
\hline & $\begin{array}{l}\text { 6. Use Integrated Pest Management (IPM) and biocontrol measures for } \\
\text { pest and disease control; use potable water for sprays. }\end{array}$ \\
\hline & $\begin{array}{l}\text { 7. Observe National Organic Program standards for use of } \\
\text { compost tea spray and drenches on crops and soil }\end{array}$ \\
\hline
\end{tabular}

\section{ENTERIC PATHOGEN SURVIVAL}

Environmental conditions such as high humidity, low temperatures, and low ultraviolet radiation, which are frequently present during cooler periods in high tunnels, individually are conducive to enhanced survival of enteric pathogens. However, no data are available to determine the extent to which these high tunnel conditions actually prolong survival in soil or on vegetables that contact the soil or whether GAPs or GHPs are adequate to protect food safety in these situations. In a recent high tunnel survival study involving a nonpathogenic strain of $E$. coli O157:H7 TT12B (Feng et al., 2001), leaves of old-lower-shaded, young-upperexposed, and youngest-partially exposed emerging crown leaves of spinach (Spinacea oleracea L.) cv. Whale were inoculated with $100 \mu \mathrm{L}$ of manure extract [average $2.3 \times 10^{5}$ colony-forming units (CFU)/leaf] or uninoculated extract. The purpose of this test was to determine if the $E$. coli would grow or decline on leaves under high tunnel conditions. The enteric pathogen load was rapidly reduced (unpublished data). All plants were grown 4 months in soil amended with mature compost determined to have undetectable concentrations of E. coli, Salmonella spp., and Listeria monocytogenes. Plants were irrigated with drinking quality water as needed during the 4-week survival study period from Mar. through Apr. 2008 without supplemental fertilizer; no irrigation water contacted inoculated leaves. Duplicate tunnels covered with film either transmitted ambient solar ultraviolet radiation from 290 to $400 \mathrm{~nm}$ (+ultraviolet) or blocked ultraviolet wave- lengths below $380 \mathrm{~nm}$ (-ultraviolet) as previously reported (Krizek et al., 2005a). Both films transmitted comparable amounts of photosynthetically active radiation (400 to $700 \mathrm{~nm}$ ). At each of five sample events, populations of $E$. coli were determined using a most-probable number enrichment method followed by selective media plating of all six replicates of each leaf locus sample set in each of four high tunnels. In general, E. coli on leaves declined $2 \log _{10} \mathrm{CFU} / \mathrm{leaf}$ in the first $24 \mathrm{~h}$ after inoculation regardless of leaf age, position on the plant, high humidity, or ultraviolet exposure status. Steady decline continued over $28 \mathrm{~d}$ such that E. coli populations were either on average undetectable (young-top leaves and youngest-crown leaves) to just barely detectable, remaining on average at $11 \mathrm{CFU} /$ inoculated leaf by Day 28 . Persistence of very low numbers of $E$. coli on contaminated plant tissue is consistent with reports from fresh produce studies (Mukherjee et al., 2004) and has important implications for the need to maintain a high degree of hygiene relative to postharvest handling, use of water, and commodity storage temperatures. These types of factors apply equally to organic and conventionally produced commodities.

\section{PHYTONUTRIENTS}

In addition to microbial quality, organic production has been reported to have a positive effect on the phytonutrient (polyphenolic and antioxidant) content of fruits and vegetables (Zhao et al., 2006). Compost use during growth of strawberry (Fragaria $\times$ ananassa Duch.) cultivars Allstar and Hon- eoye was specifically associated with increased content of antioxidants (Wang and Lin, 2003). Likewise, with compost soil amendments and other organic practices, the total concentration of three major phenolic acids, caffeic acid, p-coumaric acid, and ferulic acid, as measured by high-performance liquid chromatography from tomato fruit (Lycopericon esculentum Mill.) cultivars Oregon Spring and Red Sun was $\approx 20 \%$ higher under +ultraviolet than under-ultraviolet high tunnels at the Beltsville Research Center (Luthria et al., 2006). In addition, selective ultraviolet wavelength transmission by plastic film type-enhanced fruit yields in both cultivars were greater with + ultraviolet than with -ultraviolet conditions and texture of 'Red Sun' was rated better under + ultraviolet than under -ultraviolet or in comparison with commercial field or hydroponically grown fruits (Krizek et al., 2005b, 2006).

Given the health benefits from dietary intake of fruits and vegetables high in vitamins, minerals, and secondary phytochemicals (carotenoids, anthocyanins, flavonoids, and other phenolic compounds), production that enhances the dietary value of these commodities is desirable. Increasing our understanding of how and which production practices enhance phytonutrient content of various cultivars while reducing the risk of microbial contaminants that lead to illness among consumers is essential. High tunnels and related protected horticultural structures offer growers a range of beneficial characteristics that make them compatible with organic as well as conventional production of fresh fruits and vegetables. Further research will be needed to address factors related to the food safety, crop protection, and quality of fresh produce in organic and conventionally managed high tunnels.

\section{Literature Cited}

Bowman, D.D. 2009. Manure pathogens.. McGraw Hill, New York, NY.

Cantliffe, D.J., J. Funes, E. Jovicich, A. Paranjpe, J. Rodriguez, and N.L. Shaw. 2003. Media and containers for greenhouse soilless grown cucumbers, melons, peppers, and strawberries. Acta Hort. 614:199-203.

Cieslak, P.R., T.J. Barrett, P.M. Griffin, K.F. Gensheimer, G. Beckett, J. Buffington, and M.G. Smith. 1993. Escherichia coli O157:H7 infection from a manured garden. Lancet 342:367.

Cooper, J., U. Niggli, and C. Leifert. 2007. Handbook of organic food safety and quality. Woodhead Publishing Ltd., Cambridge, UK.

Feng, P., M. Dey, A. Abe, and T. Takeda. 2001. Isogenic strain of Escherichia coli $\mathrm{O} 157: \mathrm{H} 7$ that has lost both shiga toxin 1 and 2 genes. Clin. Diagn. Lab. Immunol. 8:711-714.

Green, C. 2008. Organic production-Data sets. USDA, Economic Research Service 2008. 8 Sept. 2008. <http://www.ers.usda.gov/data/organic $>$.

Ingram, D.T. and P.D. Millner. 2007. Factors affecting compost tea as a potential source of Escherichia coli and Salmonella on fresh produce. J. Food Prot. 70:828-834.

Jett, L.W. and J. Quinn. 2005. Growing cucumbers within a high tunnel (Missouri). In: Maynard, 
E.T. and C.C. Gunter (eds.). Midwest vegetable variety trial report for 2005. Bulletin No. B17810. Purdue University, West Lafeyette, IN.

Krizek, D.T., H.D. Clark, and R.M. Mirecki. 2005a. Spectral properties of selected UVblocking and UV-transmitting covering materials with application for production of high-value crops in high tunnels. Photochem. Photobiol. 81:1047-1051.

Krizek, D.T., P.D. Millner, M.J. Camp, H.D. Clark, M.G. Davis, B. Butler, J.R. Teasdale, D.R. Fravel, S. Reynolds, R.A. Mangum, and T.V. Currier. 2005b. Disease and management challenges encountered during the first year of growing tomatoes in high tunnels in Beltsville, MD. HortScience 40:1071.

Krizek, D.T., R.A. Saftner, E. Park, J.A. Abbott, M.J. Camp, and H.D. Clark. 2006. Yield data from 2005 and instrumental and sensory evaluation of tomato fruits from plants grown in high tunnels at Beltsville, MD or obtained from commercial sources. HortScience 41:1083.

Lamont, W.J., Jr, M.D. Orzolek, E.J. Holcomb, K. Demchak, E. Burkhart, L. White, and B. Dye. 2003. Production system for horticultural crops grown in the Penn State High Tunnel. HortTechnology 13:358-362.
Luthria, D.L., S. Mukhopadhyay, and D.T. Krizek. 2006. Content of total phenolics and phenolic acids in tomato (Lycopersicon esculentum Mill.) fruits as influenced by cultivar and solar UV radiation. J. Food Compost. Anal. 19:771777.

Mukherjee, A., D. Speh, E. Dyck, and F. DiezGonzalez. 2004. Preharvest evaluation of coliforms, Escherichia coli, Salmonella, and Escherichia coli O157:H7 in organic and conventional produce grown by Minnesota farmers. J. Food Prot. 67:894-900.

NBS. 2006. An analysis of markets, trends, competition and strategy in U.S. organic foods: 1996-2010. National Business Journal Organic Foods Report: Penton Media, Inc., Boulder, CO.

Nelson, P.V. 1997. The contamination of organic produce by human pathogens in animal manures. 17 Aug. 2008. <http://eap.mcgill.ca// SFMC_1.htm $>$. Ecological Agriculture Projects, Faculty of Agricultural and Environmental Sci., McGill Univ. (Macdonald Campus), Ste-Anne-de-Bellevue, QC, Canada.

Peet, M.M., J.M. Rippy, P.V. Nelson, and G.L. Catignani. 2004. Organic production of greenhouse tomatoes utilizing the bag system and soluble organic fertilizers. Acta Hort. 659:707719.
Romanowski, R. 1981. Environmental control structures, p. 119-127. In: Plucknett, D.L. and H.L. Beemer, Jr. (eds.). Vegetable farming systems in China. Westview Press, Boulder, CO.

Scheuerell, S.J. and W.F. Mahaffee. 2004. Compost tea as a container medium drench for suppressing seedling damping-off caused by Pythium ultimum. Phytopathology 94:11561163.

Stoffella, P.J. and B.A. Kahn. 2001. Compost utilization in horticultural cropping systems. CRC Press, Boca Raton, FL.

USDA. 2000. National Organic Program, 7 CFR Part 205. The Organic Foods Production Act of 1990, as amended (7 U.S.C. 6501-6522) 65 FR 80637, 21 Dec. 2000. US Department of Agriculture, Agricultural Marketing Service, Washington, DC.

Wang, S.Y. and H.S. Lin. 2003. Compost as a soil supplement increases the level of antioxidant compounds and oxygen radical absorbance capacity in strawberries. J. Agr. Food Chem. 51:6844-6850.

Zhao, X., E.E. Carey, W. Wang, and C.B. Rajashekar. 2006. Does organic production enhance phytochemical content of fruit and vegetables? Current knowledge and prospects for research. HortTechnology 16:449-456. 